\title{
Bone Marrow Stem Cell Committed to the Basophil Lineage
}

National Cancer Institute

\section{Source}

National Cancer Institute. Bone Marrow Stem Cell Committed to the Basophil Lineage. NCI Thesaurus. Code C43227.

A primitive, undifferentiated blood cell which can undergo division and will give rise to a cell in the basophil lineage. 